\title{
أحكام الحكرة والإحتكار في معاملات المالية دراسة المقارنة بين أراء الفقهاء والمحدثين في معامات المالين
}

\author{
ديسمادي سهارالدين
}

Fakultas Ekonomi dan Bisnis. UIN Syarif Hidayatullah Jakarta.

Jl. Ir. H. Juanda No.95 Ciputat. Jakarta Selatan

E-mail: desmadi.saharuddin@uinjkt.ac.id

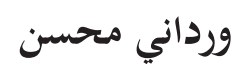

Dosen Universitas Islam Negeri Bandung, Dpk. Stai-Laroiba Cibinong

Jl. Kampung Sawah 9 RT 002/02, Keracak Leuwiliang, Bogor.

E-mail: wardhani.m@gmail.com

\begin{abstract}
Monopoly Law and Stockpiling Commodities in Trade Transactions: A Comparison between Scholars of Fiqh and Hadith Opinions. Trade transactions conducted to gain an advantage in bad ways is prohibited by Islamic Law. It is a sin or despotic practice when someone saves a commodity not to be sold and reduced the availability of existing goods market and cause the expensiveness of shortages. Then prices could also be rising because of increasing demand on certain commodities, even there is no scarcity.Someone is allowed to store his belongings to the extent desired time and then sell when the price is already more expensive in order to make a profit.
\end{abstract}

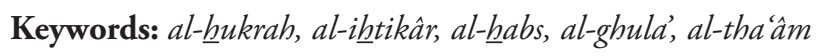

\begin{abstract}
Abstrak. Hukum Monopoli dan Penimbunan Komoditi dalam Transaksi Perdagangan: Perbandingan Pendapat Ulama Fikih dan Hadis. Transaksi perdagangan yang dilakukan untuk mendapatkan keuntungan dengan cara yang tidak baik dilarang oleh Syariat Islam. Menyimpan suatu komoditas untuk tidak dijual dan mengurangi ketersediaan barang yang ada dipasar sehingga menyebabkan kelangkaan agar harganya menjadi mahal adalah perbuatan dosa.Kenaikan harga terhadap suatu komoditi dapat disebabkan oleh beberapa faktor, diantaranya penahanan yang berupa penimbunan yang menyebabkan kelangkaan dan akhirnya harga menjadi melambung, dalam ajaran Islam ini merupakan suatu kezaliman. Kemudian harga juga bisa menjadi naik karena permintaan yang terus meningkat terhadap komoditi tertentu, walaupun tidak terdapat kelangkaan. Seseorang dibolehkan menyimpan barang-barang miliknya sampai batas waktu yang diinginkan dan kemudian menjualnya apabila harga sudah lebih mahal supaya mendapatkan keuntungan.
\end{abstract}

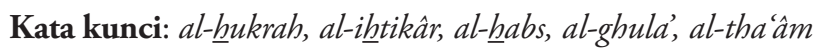

$$
\begin{aligned}
& \text { وذكر في اللسان معنى آخر فقال: لا ومنه حديث عثمان }
\end{aligned}
$$

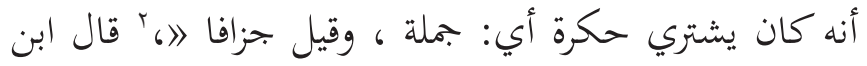

$$
\begin{aligned}
& \text { الأثير : إ الاحتكار : حبس الطعام لطلب غالائه، والاسم منه }
\end{aligned}
$$

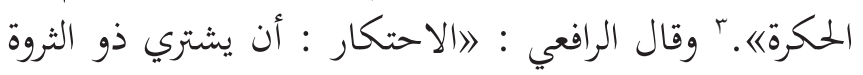

$$
\begin{aligned}
& \text { الطعام وقت الغلاء ولا يدعه للضعفاء ويجبسه ليبيعه منهم }
\end{aligned}
$$

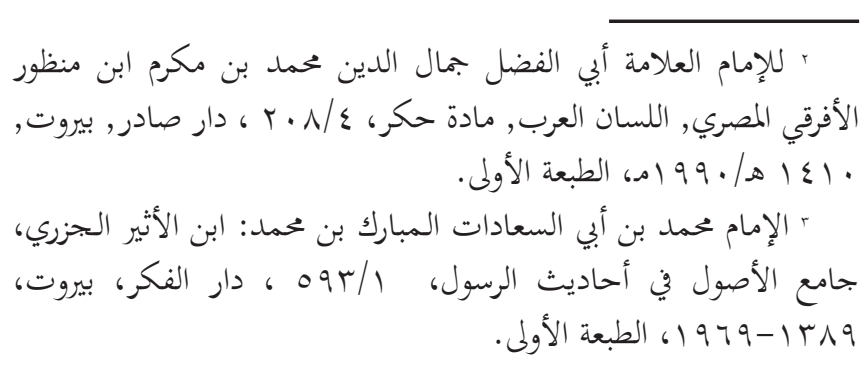

المقلمة

$$
\begin{aligned}
& \text { قال ابن فارس: لا الحاء ، والكاف، والراء أصل واحد، وهو }
\end{aligned}
$$

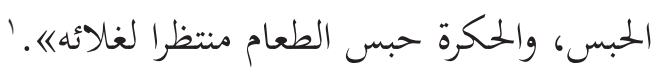

$$
\begin{aligned}
& \text { وقال في اللسان: \ا الحكر : ادخار الطعام للتربص وصاحبه }
\end{aligned}
$$

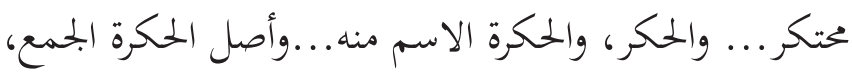

$$
\begin{aligned}
& \text { والإمساك. }
\end{aligned}
$$

Recived: 7th January 2014, revised: 7th March 2014, accepted: 12th May 2014.

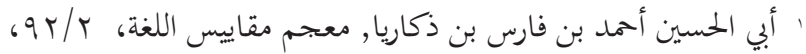

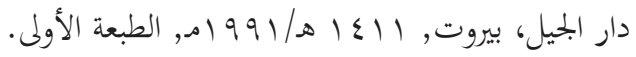


قلت لابن عباس: كيف ذاك ؟ قال : ذاك دراهم بدارهم والطعام مرجأ ).

r. حديث ابن عمر رضي الله عنهما يقول: قال رسول الله

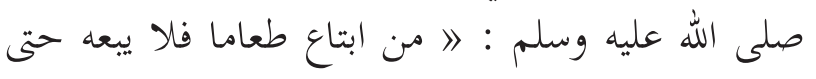

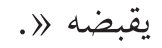

ع ـ حديث مالك بن أوس سمع عمر بن الخطاب رضي الله عنه

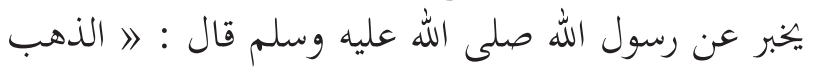

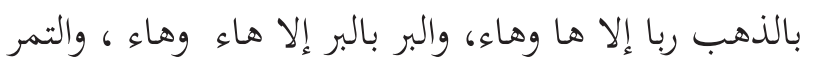

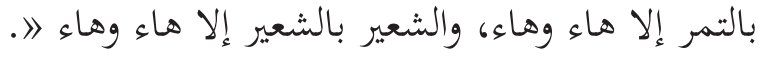
في هذه الترجمة أمور تحتاج إلى إيضاح مقصود البخاري بها:

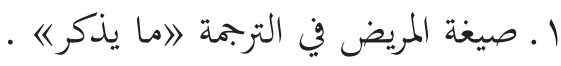
r r بيع الطعام.

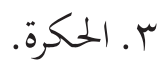

\section{مناسبة الأحاديث التي أوردها البخاري}

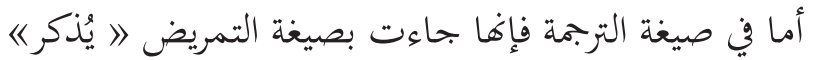
فلم هذه الصيغة؟ هل يوجد خلاف في بيع الطعام أم ماذا ؟ صا؟

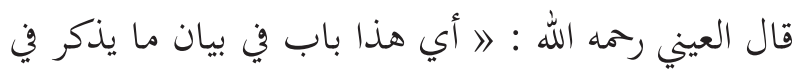

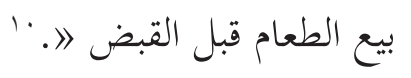

وفي ذلك نظر لأن البخاري رحمه الله أورد تربمة خاصة لبيع

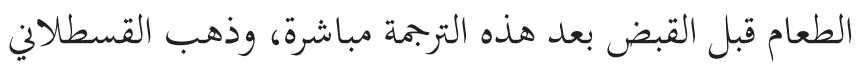

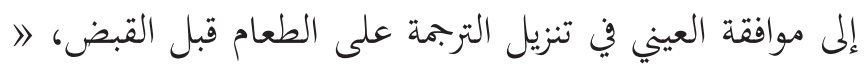

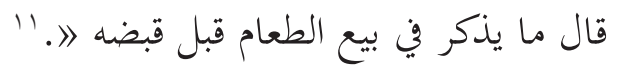

وقال في بيان مناسبة حديث ابن عمر للترجمة : لا مطابقته

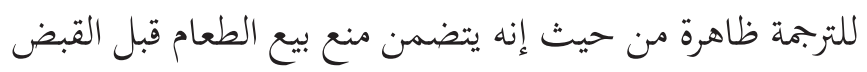

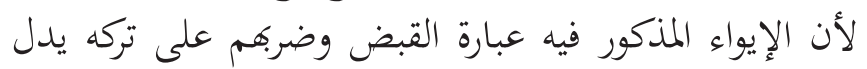

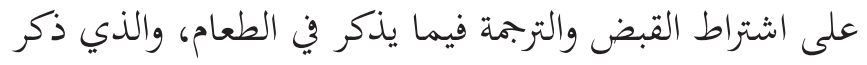

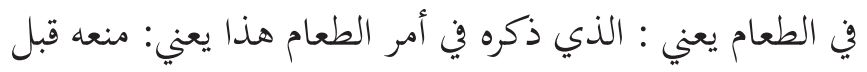

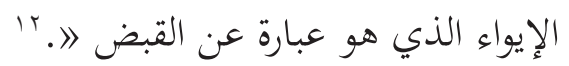

بدر الدين العيني أبي محمود بن أحمد العيني، عمدة القاري شرح

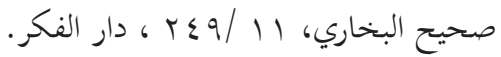

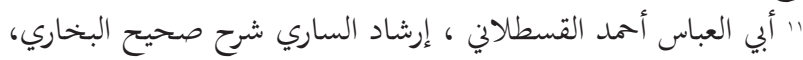

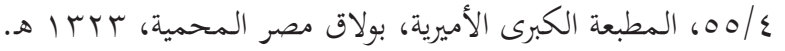

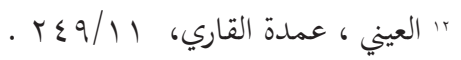

بأكثر عند اشتداد حاجاتمم 》ا.؛

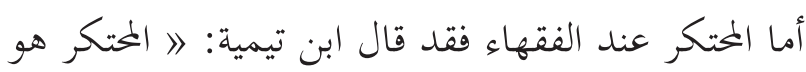

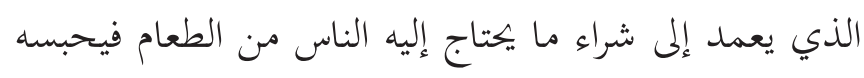
عنهم ويريد إغلاءه عليهمبه. وقال الكاساني رحمه الله : 》 تفسير الاحتكار : أن يشتري

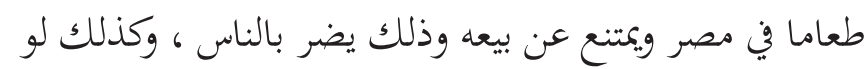

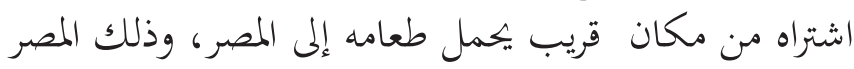

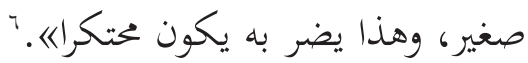
وقال ابن عابدين رحمه الله : الالاحتكار شرعا : اشتراء

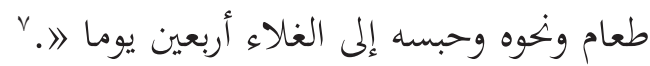
وقال في المنتقى : \ا الاحتكار هو : الادخار للمبيع وطلب

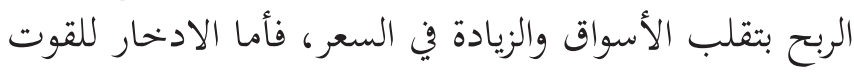

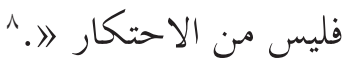

\section{الحكرة وما يتعلقبها من الأحاديث}

ذكر البخاري رحمه الله في ترجمته : 》ا ما يذكر في بيع

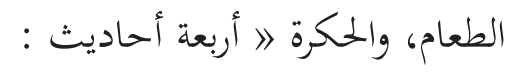

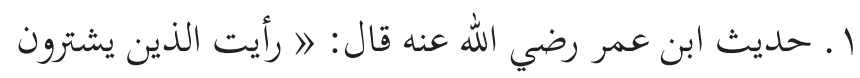

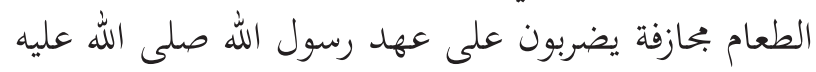

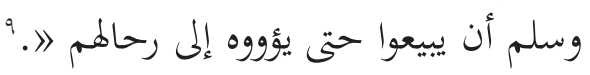

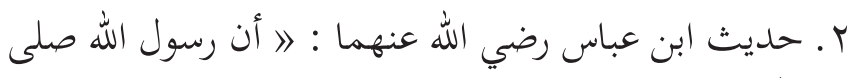

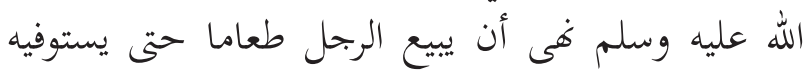

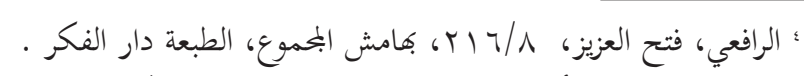

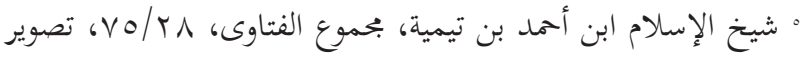

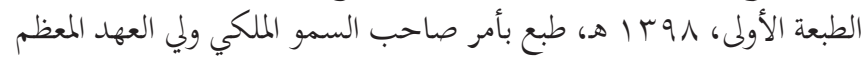

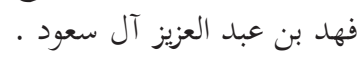

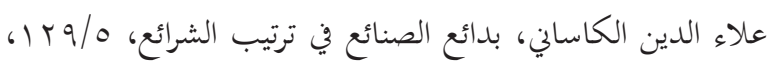

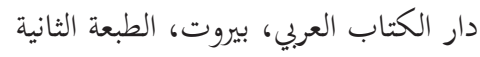

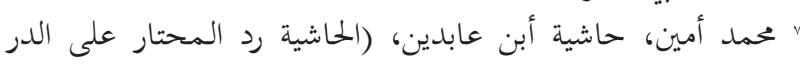

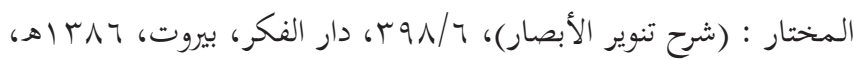
الطبعة الثانية.

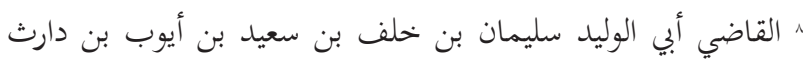

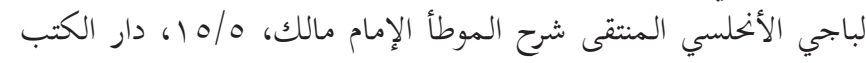

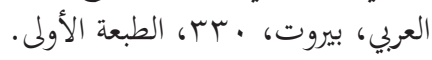

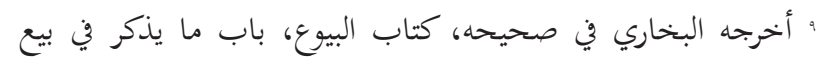

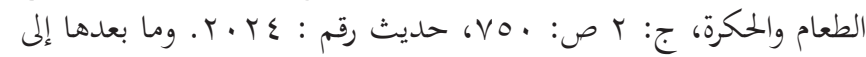

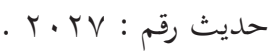


والبخاري قيدها.

فقال في احتكار الطعام: أورد تحتها جملة من الأحاديث

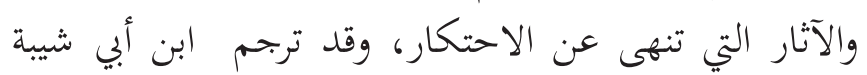

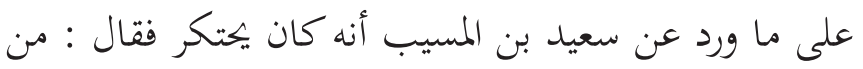

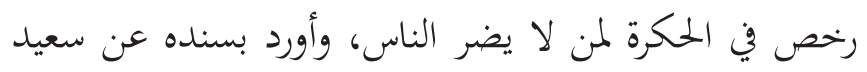
بن المسيب النوى، والعجم، والخبط، فيحتكره. 19

وفي ترجمة المسور بن مخرمة من صفة الصفوة، قصة تدل

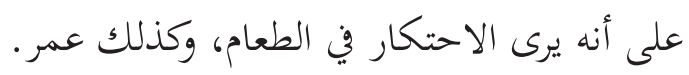

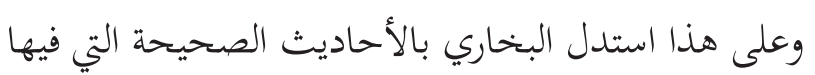

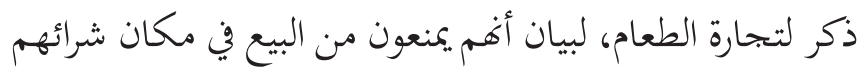

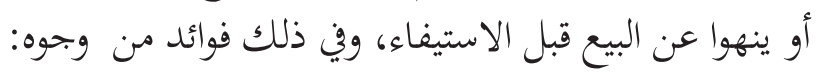

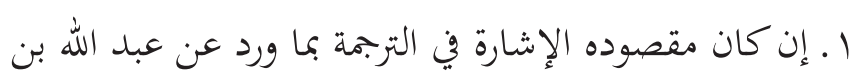
عمرو بن العاص فمقصوده تضعيفه ولذلك جعل فيل العبارة فيها ما يشعر بالتضعيف وفي صيغة التمريض. فيض.

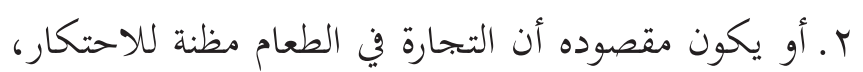

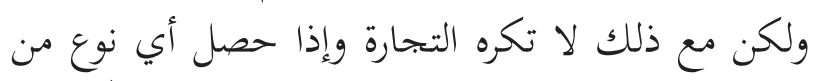

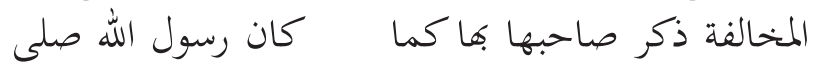
الله عليه وسلام يرسل أناسا يمنعون أهل الطعام، والتجار

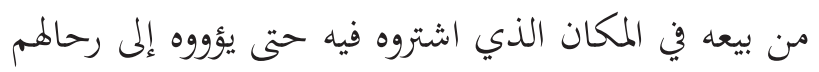
فكذلك الأمر لو حصل احتكار أيضا.

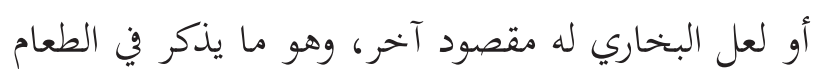

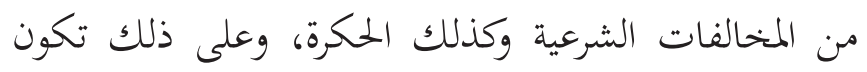

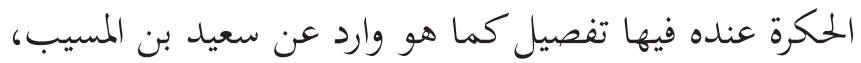
أو يفهم من الاقتران أنه يخص الاحتكار عندا بالطعام.

\section{r. الاحتكار وما يتعلقبها}

وقد ورد في الاحتكار أحاديث منها:

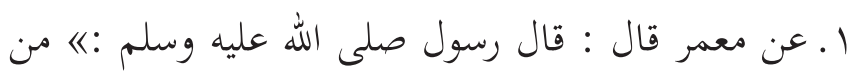

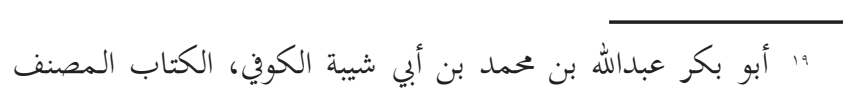

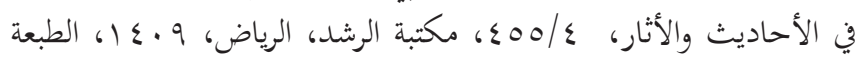
الأولى، تحقيق : كمال يوسف الأنار، الحوت عاديث.

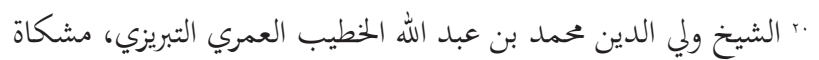

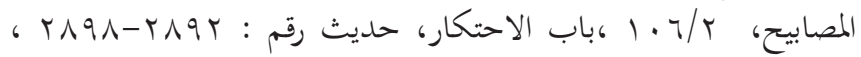

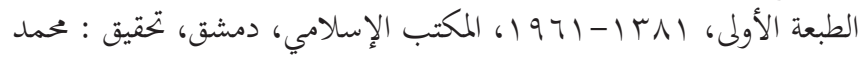

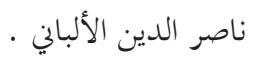

ويحتمل أن البخاري أشار إلى خلاف نقل عن بعض أهل

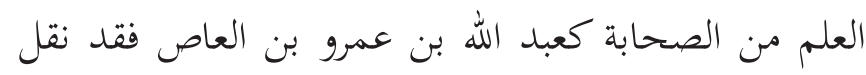

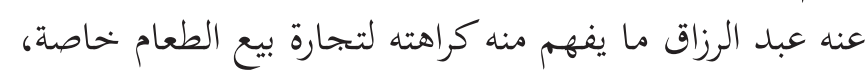
ولفظه : عن عبد الله بن عمرو بن العاص قال: ما من رجل ئل يبيع

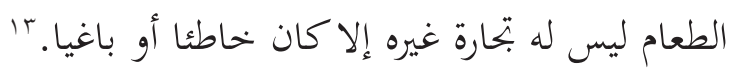

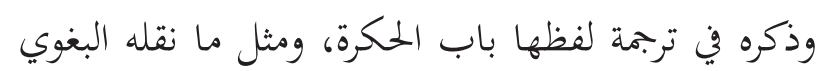

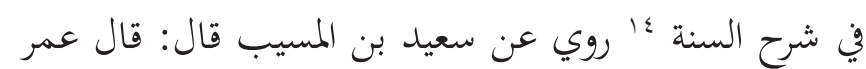
نعم الرجل فلان، لولا بيعه، وكان يبيع الطعام.

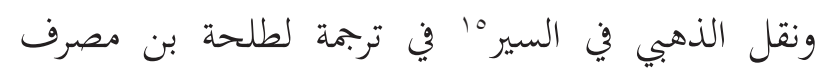

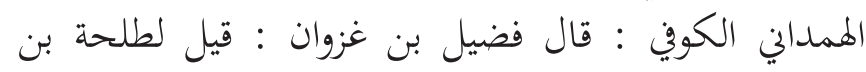

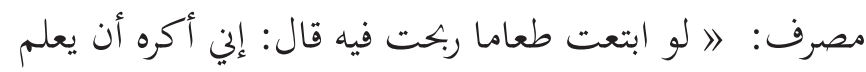

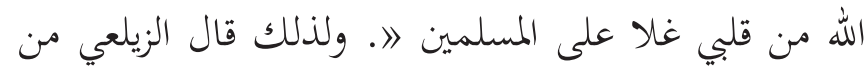

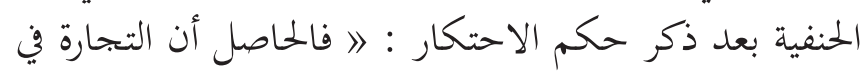

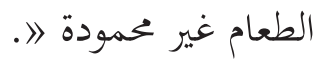
قال في تبين الحقائق : \ا غير محمودة أي : التجارة بطريق

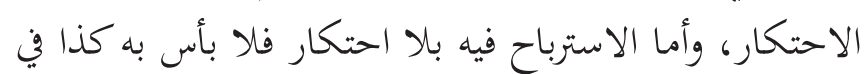

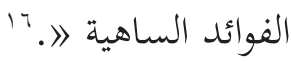
قال في الإنصاف : لا وفي كراهية التجارة في الطعام إذا لم

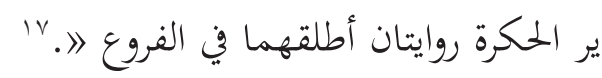
وقد سئل الإمام أحمد عن ذلك قيل: أيكره بيع الطعام،

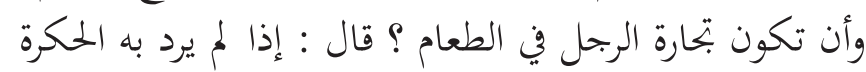

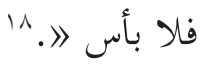
وابن أبي شيبة لما ترجم بإطلاق الترجمة كما فعل عبد الرزاق،

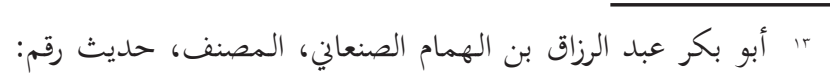

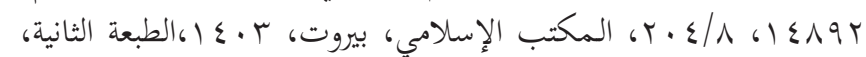

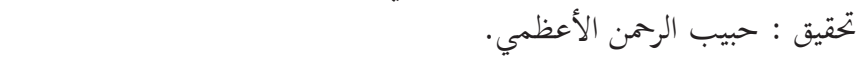

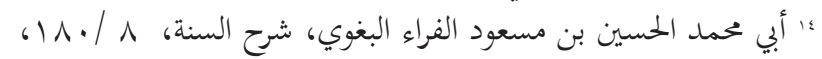

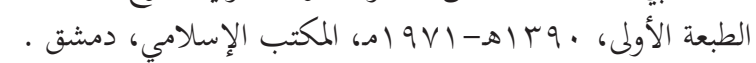

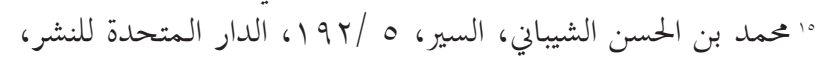

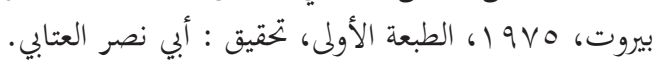

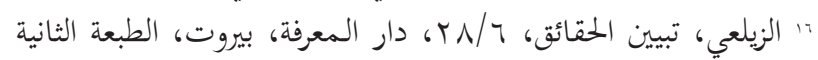

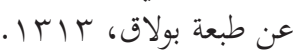

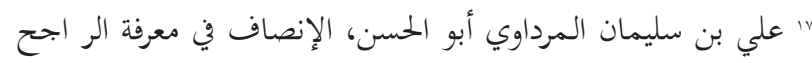

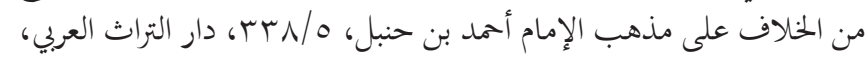

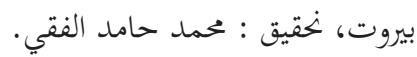

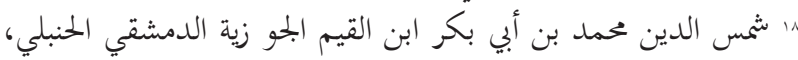

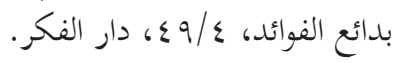


سمعت رسول الله صلى الله عليه وسلام يقول : 》ا لا يحتكر

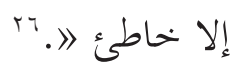

فقلت لسعيد: يا أبا محمد إنك تحتكر . قال : ومعمر كان

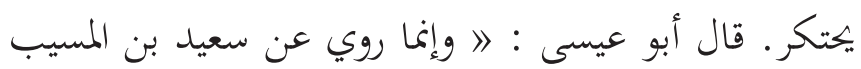

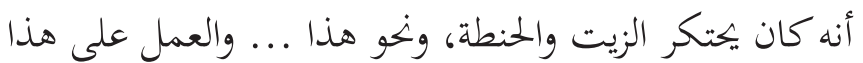

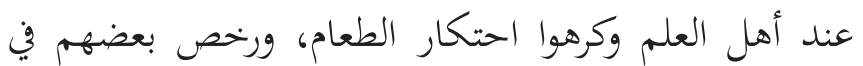
الاحتكار في غير الطعام وكروام احترا وقال ابن المبارك رحمه الله : لا لا بأس بالاحتكار في القطن،

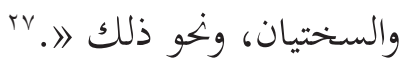
وروي عبد الزراق عن قتادة أنه كان لا يرى باحتكار البز

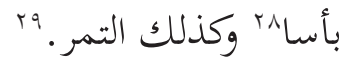
وترجم أبو داود لهذا الحديث في سننه. فقال : باب النهي عن الحكرة، وكذلك صنع الدارمي باب

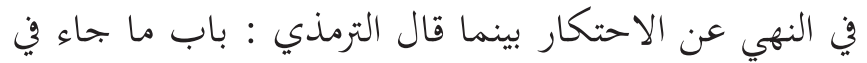

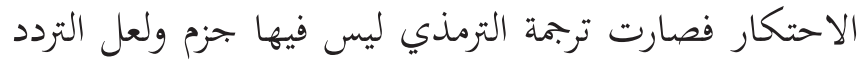
جائه من شيخه البخاري رحم الله الجميع. وروي عبد الرزاق عن سفيان قال: المختكر الذي يشتري

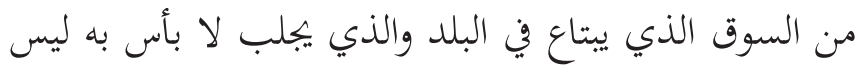

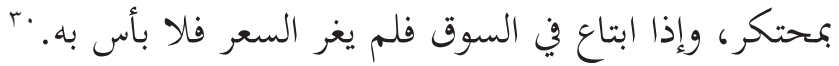
وقد ورد النهي عن الاحتكار عن عثمان، وعمر وعلي، وعبد

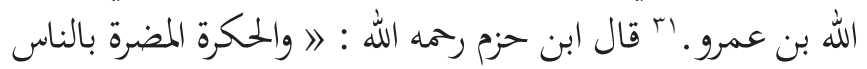

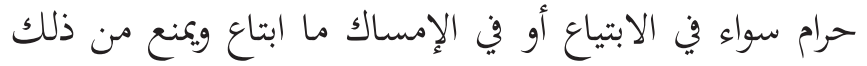

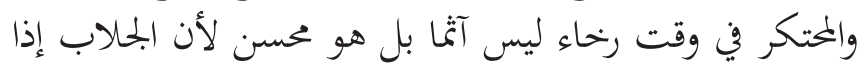

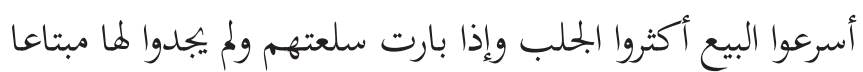

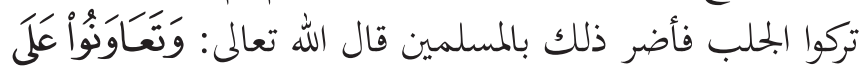

$$
\begin{aligned}
& \text { بr سنن الترمذي، باب ما جاء في الاحتكار، ج: r ص: 07V، }
\end{aligned}
$$

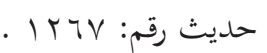

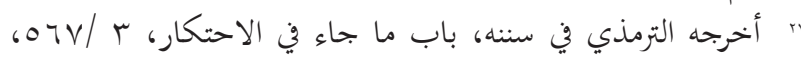

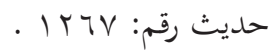

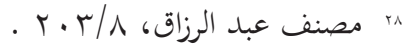

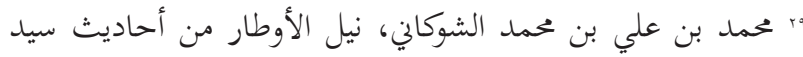

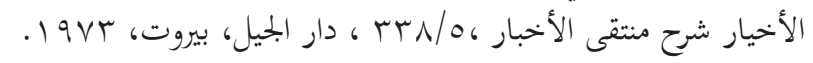

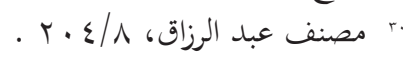

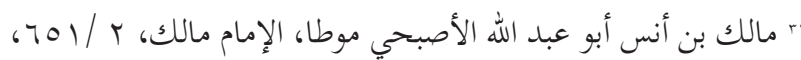

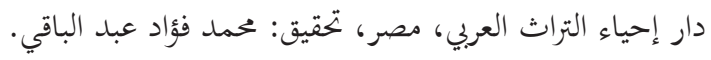

احتكر، فهو خاطئ لا، رواه مسلم بع.

r r عن عمر رضي الله عنه ، عن النبي صلى الله عليه وسلم قال

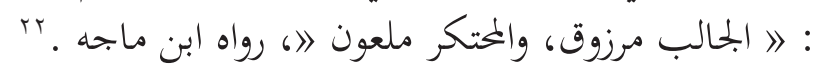

r. وعن أناس قال : غلا السعر على عهد النبي صلى الله عليه

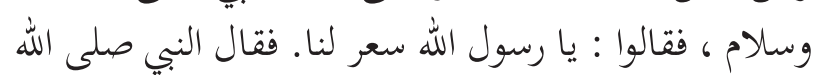

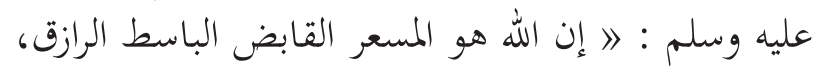

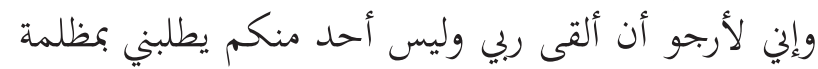

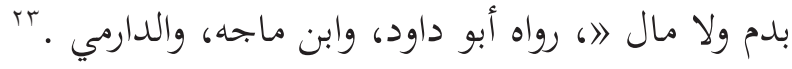
ـ ـ عن عمر بن الخطاب رضي الله عنه قال : سمعت رسول الله

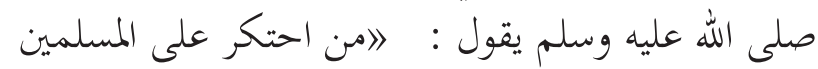

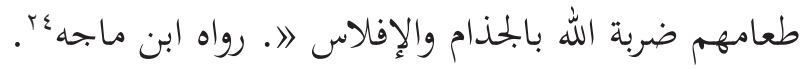
ه. عن بن عمر رضي الله عنه قال : قال رسول الله صلى اللى

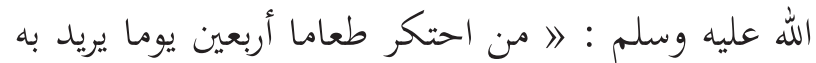

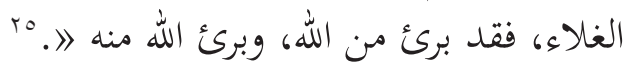

7 7. وعن معاذ، قال : سمعت رسول الله صلى الله عليه وسلام

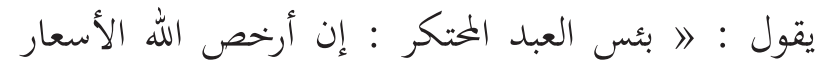

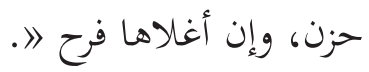

\section{أقوال أهل العلم في الاحتكار}

العلماء متفقون على النهي عن الاحتكار، ولكن بعضهم

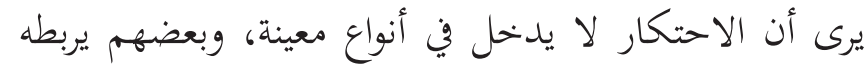
بالضرر كما سيتضح من كلامهمم:

قال الترمذي بعد إيراده لحديث معمر بن عبد الله قال:

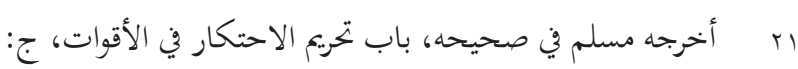

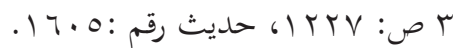

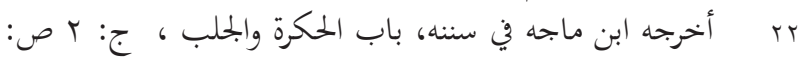
ضع人

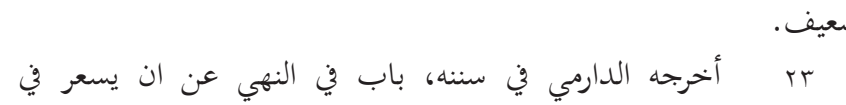

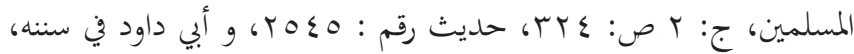

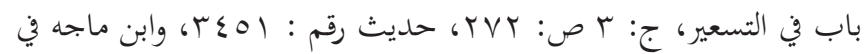

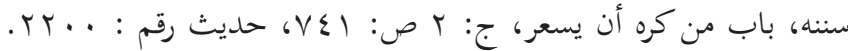

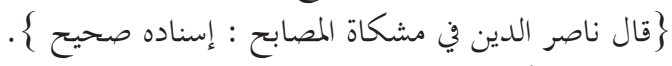

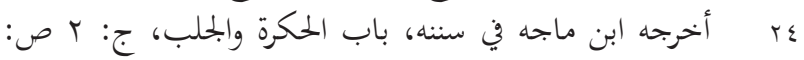

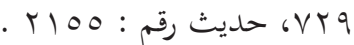

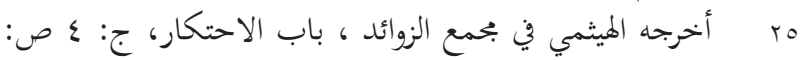

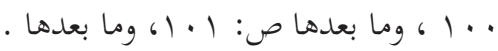


فيه، وأما غير الأقوات فلا يكرم الاحتكار فيه بكل حال

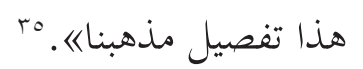

أما عند الحنفية فيقول الكاساني: 》ا ويكره الاحتكاري". ثم

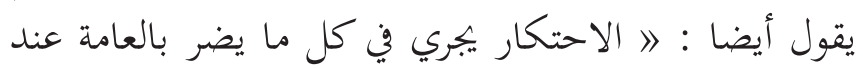

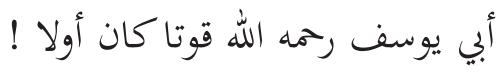

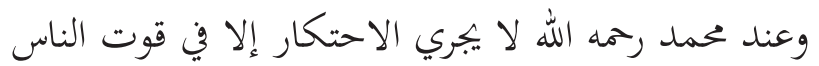

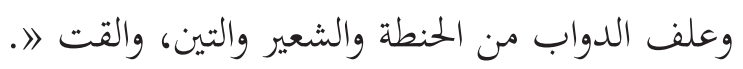

وكذلك قول أبي حنيفة بَ بل نقل عن محمد جواز الاحتكار

في الثياب. وكن تول

ثم ذكر مأخذ الأقوال فقال : \ا وجهه قول محمد رحمه الله

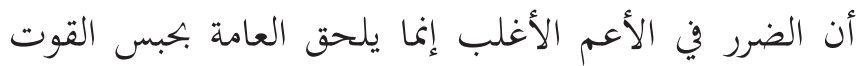

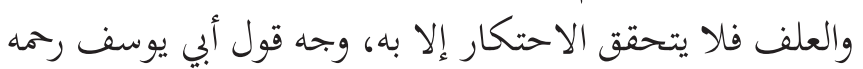

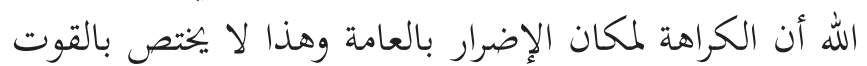
العلف اله آن الخراهن

ثم قال بعد : 》ا وأما حكم الاحتكار فيتعلق بالاحتكار

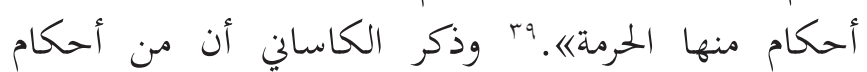

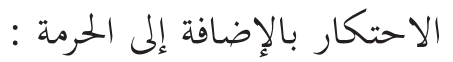

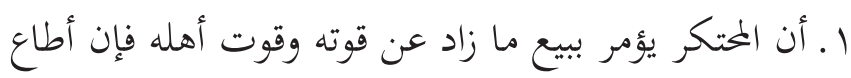

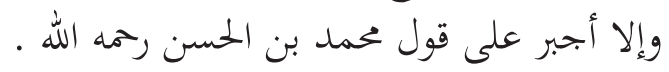

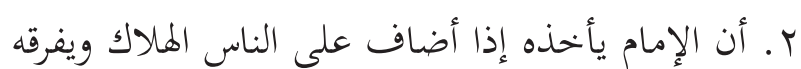

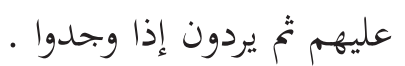

ذكر علماء الحنفية حكم بعض الصور المفترضة في الاحتخار:

ا ـ لو زرع في مزرعته ثم ادخره لا يكون محتكرا بالاتفاق. r. لو جلب من بلد غير محتكر فيه.

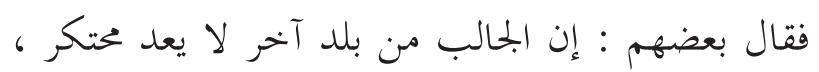
وهذا قول أبي حنفية لأنه خالص حقه لمقال الم يتعلق حق العامة به.

ror أبو زكريا يهيى بن شرف بن مري الذووي، صحيح مسلم بشرح

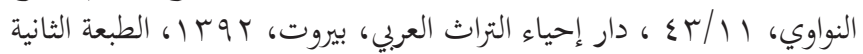

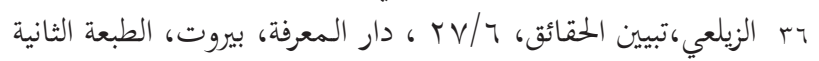

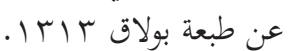
rr

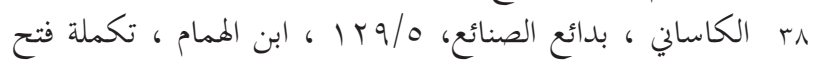

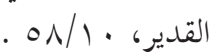

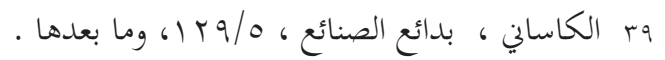

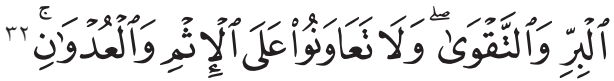

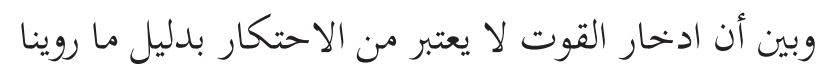

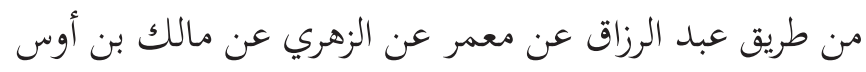

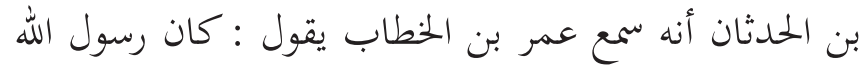

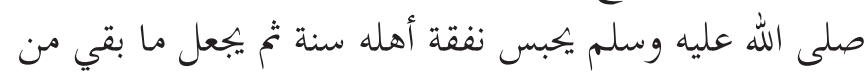

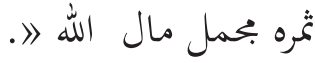
فهذا النبي صلى الله عليه وسلم قد حبس قوت أهله سنة،

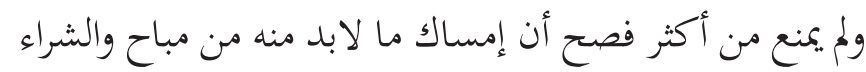

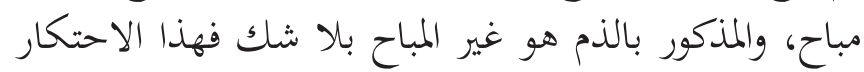

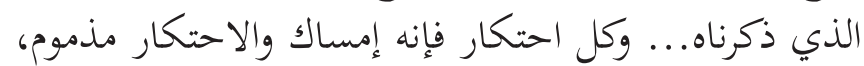

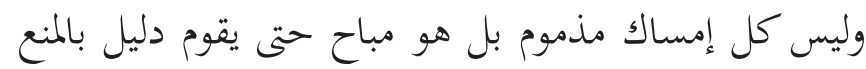

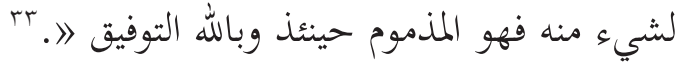
قال في المغني: \ والاحتكار المحرم ما اجتمع فيه ثلاثة شروط:

ا ـ أن يشتري شيئا أو أدخل من غلته شيئا فاحتكره لم يكن

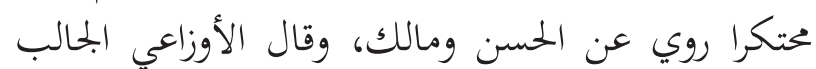

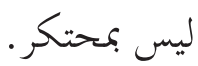

r. أن يكون المشتري قوتا قال الأثرم : سمعت أحمد يقول: إذا كان من قوت الناس فهو الذي يكرهه.

r. أن يضيق الناس بشرائه ولا يكصل ذلك إلا بأمرين :

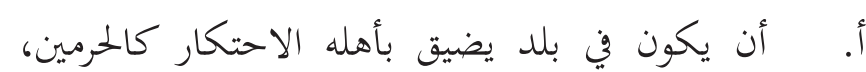

والثغور.

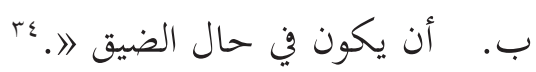
قال النووي رحمه الله : إ قال أصحابنا الاحتكار المحرم

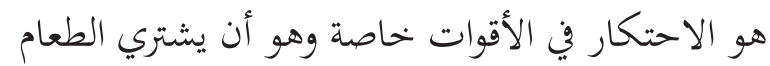

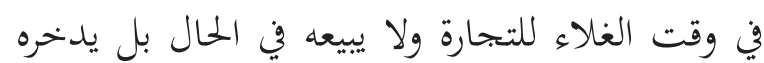

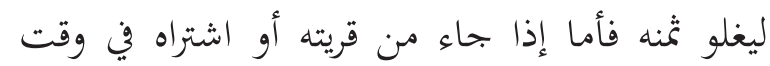

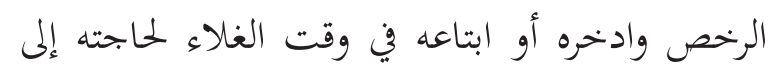

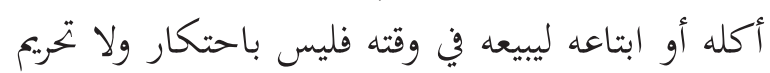

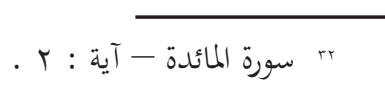

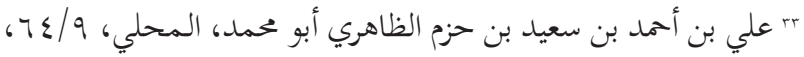

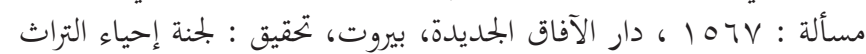

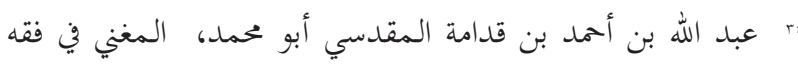

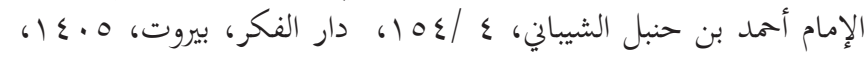
الطبعة الأولى. 
من غر دجلة والفرات《.

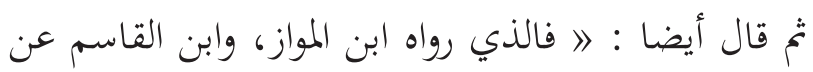

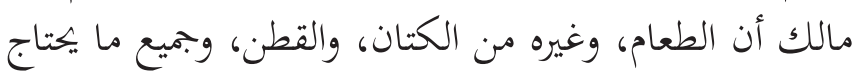

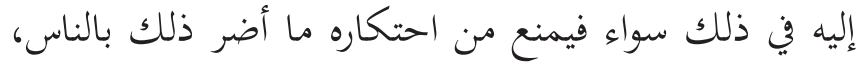
ووجحه ذلك:

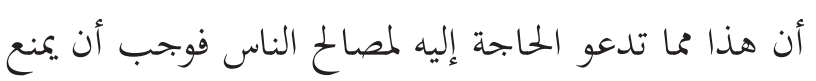

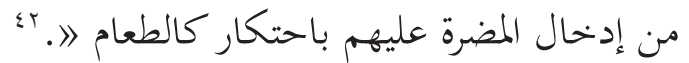

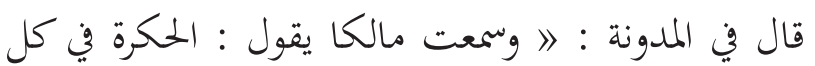
شيء في السوق من الطعام، والزيت ، والكتان، وجميع الأشياء

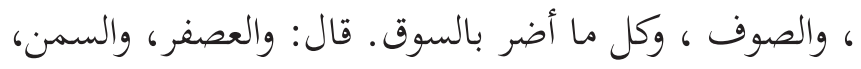
والعسل، وكل شيء .

قال مالك : إذا كان الاحتكار لا يضر بالسوق : فلا بأس به واستدل بما بلغه عن عمر بن الخطاب قال: 》 لا حكرة في

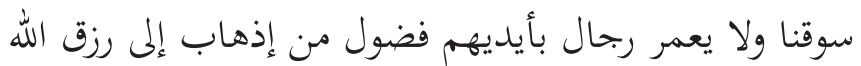

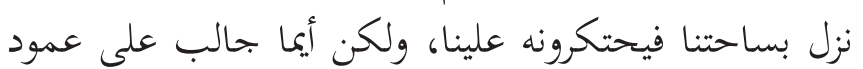
كبده في الشتاء، والصيف فذلك ضيف عمر فليبع كيف شيف شاء

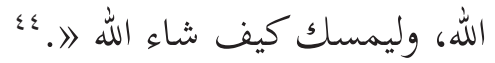
هذه هي أقوال أهل العلم في الاحتكار، ما بين موسع،

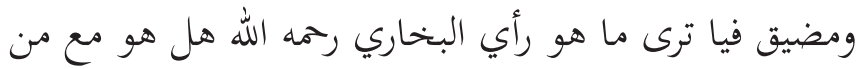

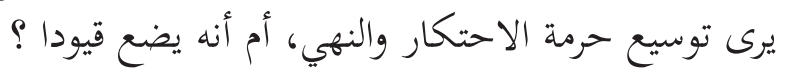
ومن مناقشة أقوال أهل العلم في حكم الاحتكار يظهر

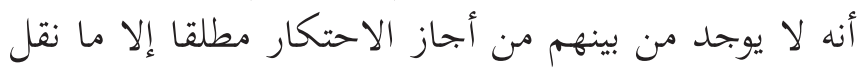

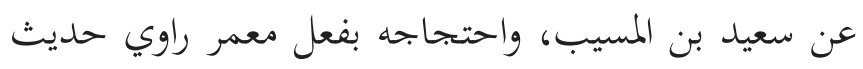

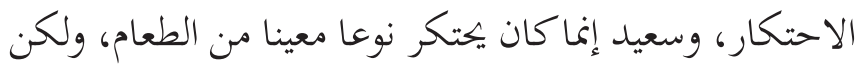

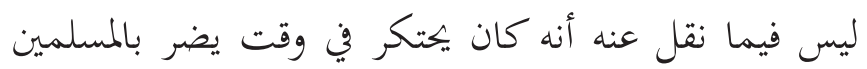

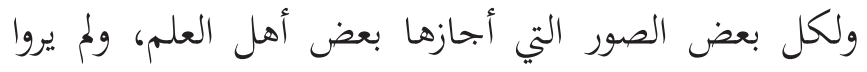

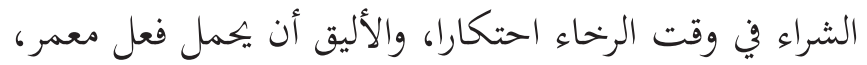

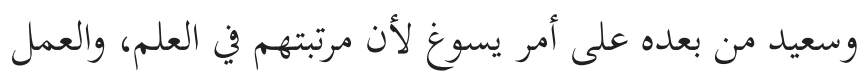

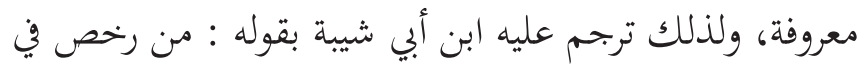
الحكرة بما لا يضر الناس.

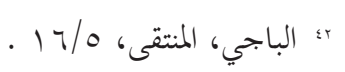

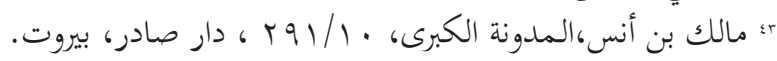

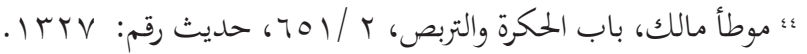

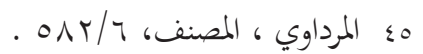

وقال أبو يوسف رحمه الله : لا إذا نقله من بلد آخر،

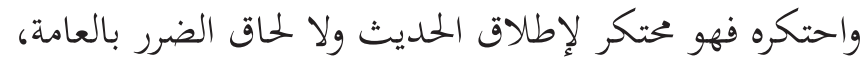

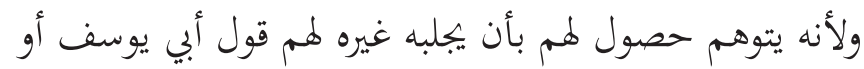

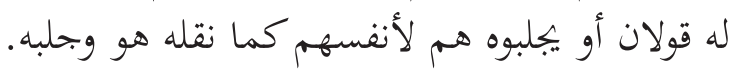

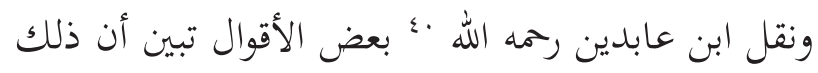

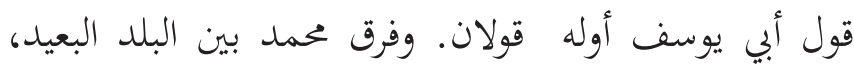
والبلد الذي يغلب الجلب منه فإن حقهم يتعلق به فيعد محتكرا

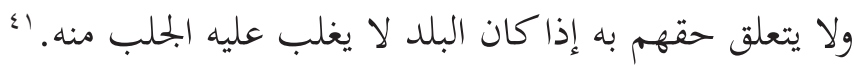
ويمكن الربط بين هذه الاجتهادات وما هو قائم، وموجود

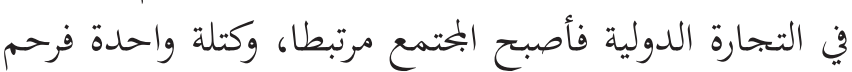

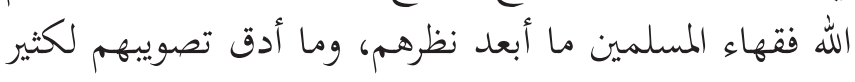

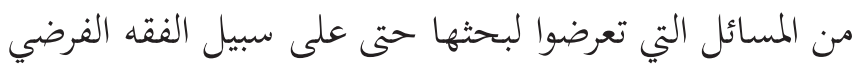

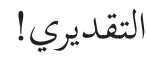
أما الإمام مالك رحمه الله ففرق بين حالين ومنع في الأولى، واختلفت عنه الرواية في الثانية. قال في المنتقى : 》ا الباب الثاني في بيان معنى الوقت الذي يمنع فيه الادخار والإحتكار. ا. ثم قال : إن لذلك حالتين أحدهما حالة ضرورة، وضيق

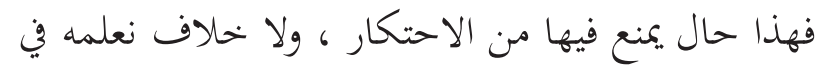
ذلك. Y. والثانية حالة كثرة وسعة فهاهنا اختلف أصحابنا.

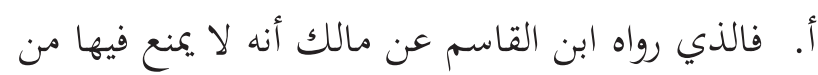

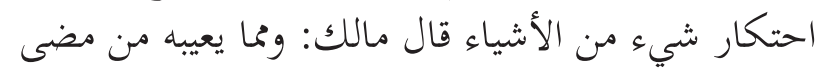

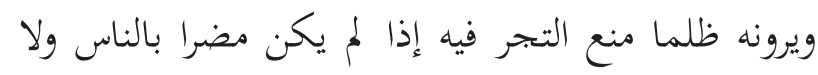
بأسواقهم.

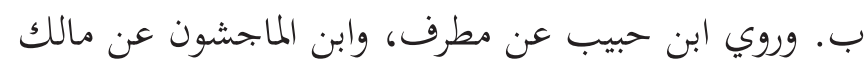

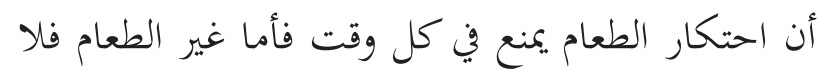

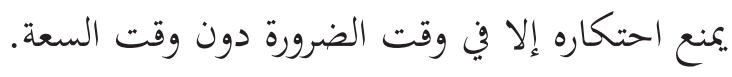
وجها ما رواه ابن القاسم أن يمنع في وقت السعة منع إسع أهل

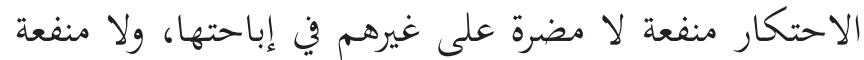

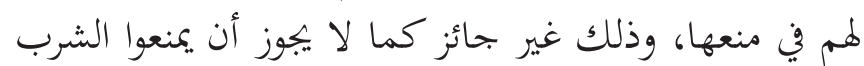

محمد أمين، حاشية أبن عابدين، (الحاشية رد المحتار على الدر

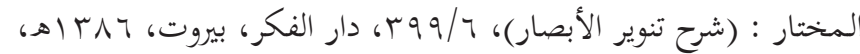
الطبعة الثانية.

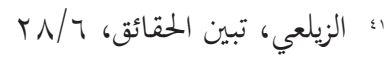


بيان الترجمة وشرح حال النبي صلى الله عليه وسلم في صيام التطوع كما ذكره الحافظ ناقلا عن ابن المنير. ب. وفي الزكاة باب ما يذكر في الصدقة للنبي صلى الله

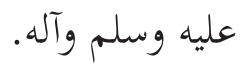
قال الحافظ ولم يعين الحكم لشهرة الخلاف فيه. ^؛ وله ج.في الصلاة قال باب ما يذكر في الفخذ، وأورد تحت

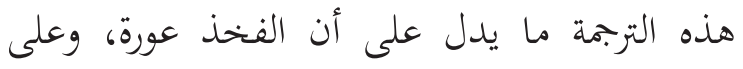

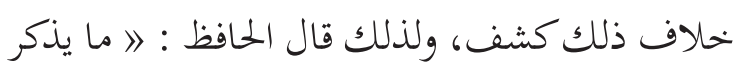

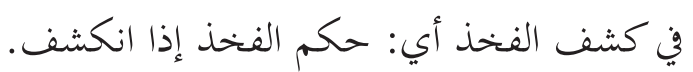

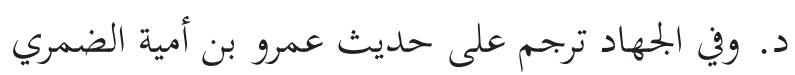

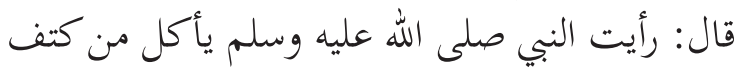

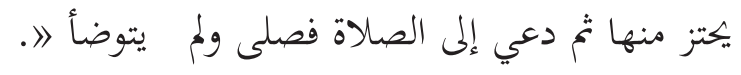
ثم أشار إلى طريق أخرى فيها زيادة : فألقى السكين. ج؛

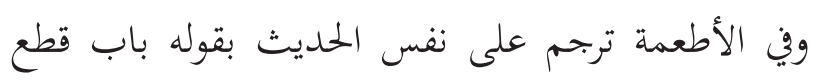

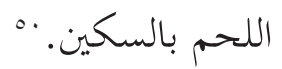

ومن كل هذه النماذج يمكن القول أن البخاري له مقاصد

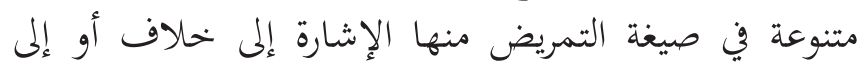

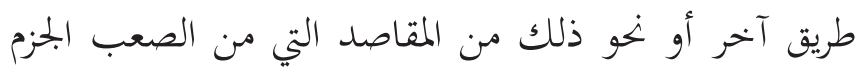

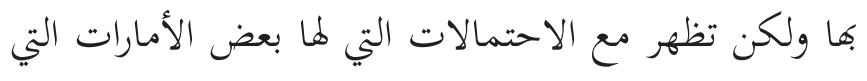
تقويها.

ولذلك فإلي أميل إلى أن البخاري يرى المنع للاحتكار إذا

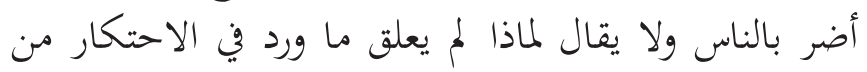

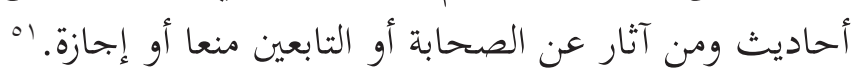

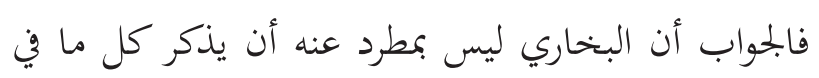

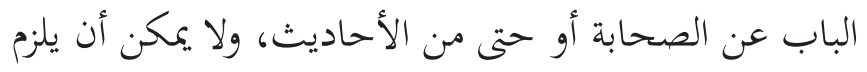

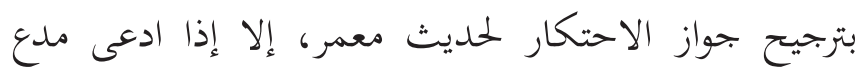

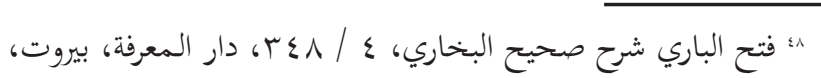

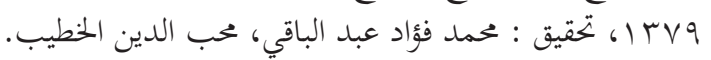

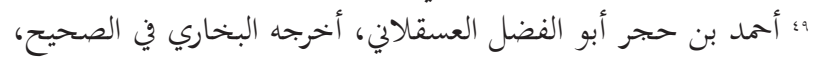

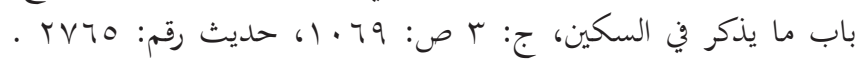

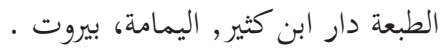

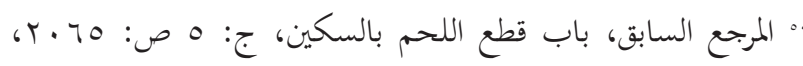

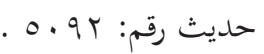

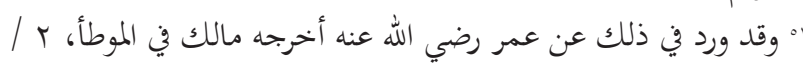

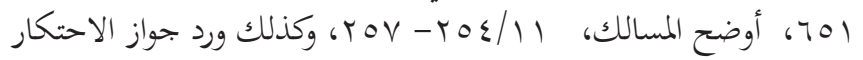

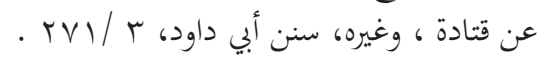

قال البغوي رحمه الله : إ الحديث - ومراده حديث معمر

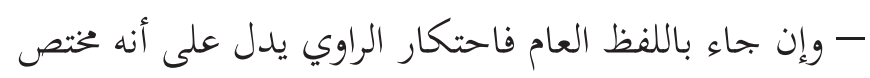

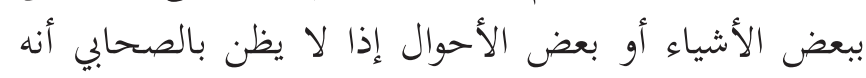

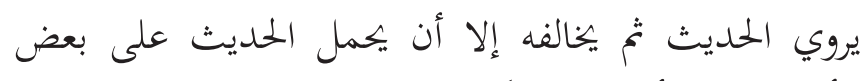

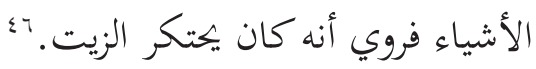

قال الشوكاني ناقلا عن ابن عبد البر رحمه الله : \اءنما إنما

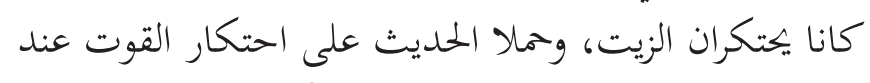
الحاجة إليه، وكذلك حمله الشافعي، وأبو حنيفة، وآخرون،

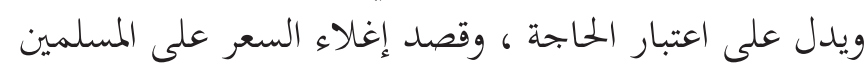
قوله في حديث معقل : ال من دخل في شيء من أسعار

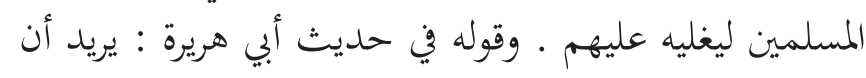

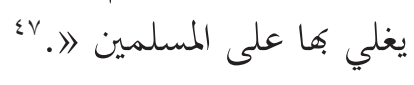

الخاتمة

والذي يظهر لنا أن البخاري رحمه الله يرى أن الاحتكار لا يجهوز، وأن من احتكر منع من ذلك ويدل على ذلك ألك أمور

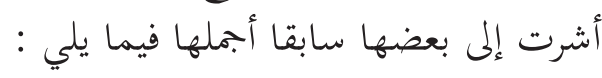
ا ـ أن البخاري رحمه الله قرن في الترجمة بين بيع الطعام وبين

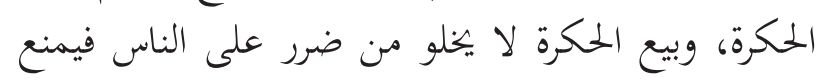

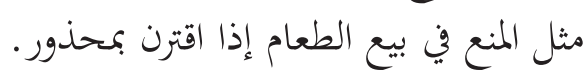

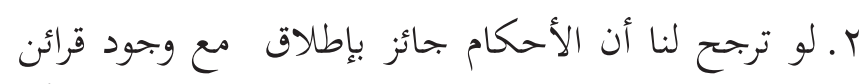

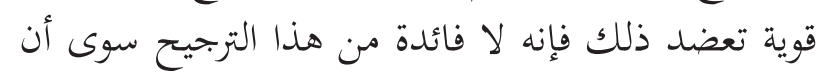

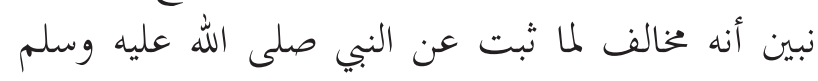

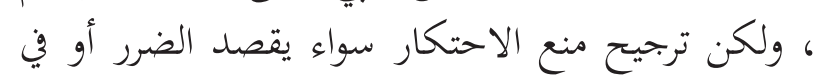

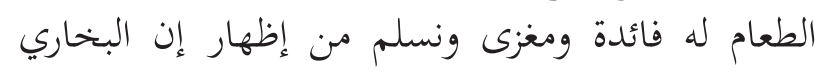

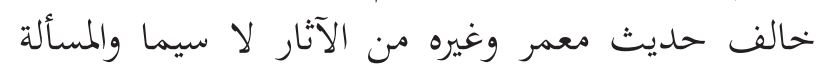
دائرة في بجال الاحتمال. r. أن لهذه الترجمة نظائر في الصحيح لا تدل على قاعدة

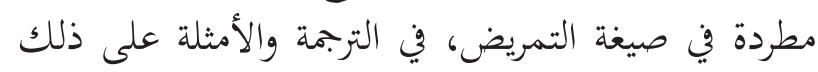
كثيرة : مطردة

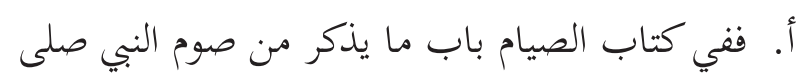

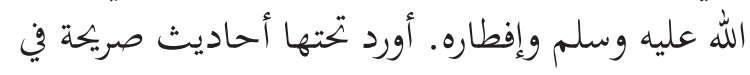

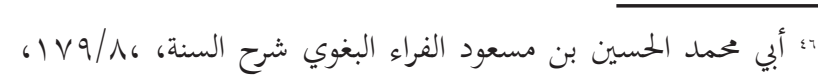

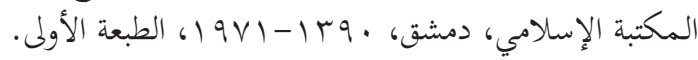

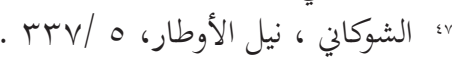


$.19 V Y-1 \varepsilon \cdot r$

البستي، ممد بن حبان بن أحمد أبو حاتم التميمي ، صحيح

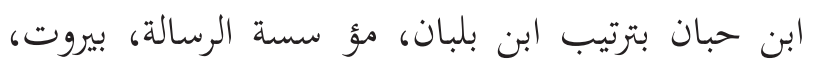

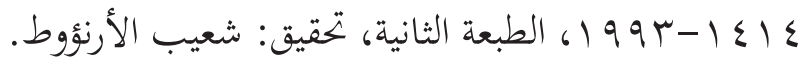

البغدادي, علي بن عمر أبو الحسن الدار قطني , سنن

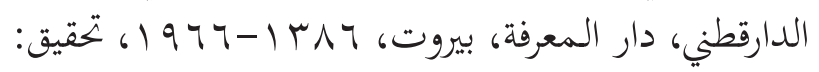
السيد عبدالله هاشم يماني المدني.

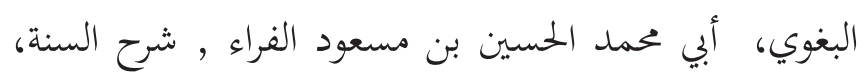

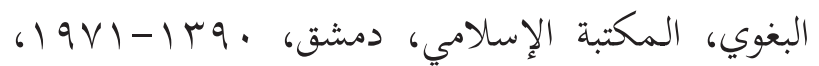

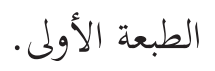

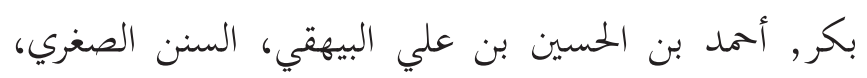

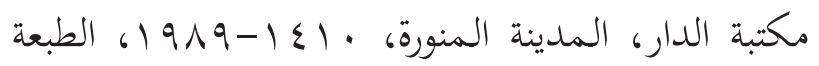

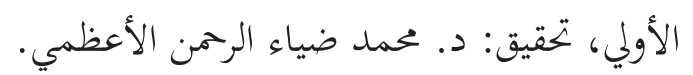

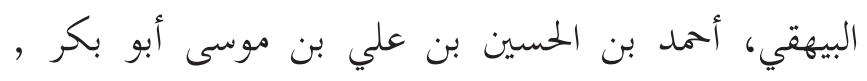

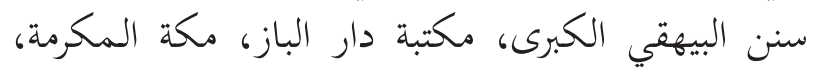

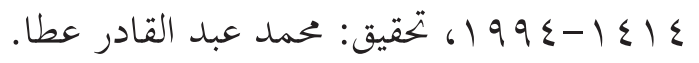
التبريزي، الشيخ ولي الدين محمد بن عبد الله الخطيب العمري,

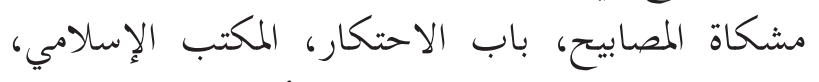

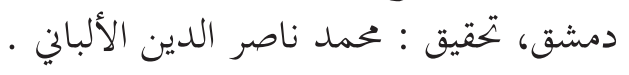

تيمية، شيخ الإسلام ابن أحمد بن , بحموع الفتاوى، تصوير

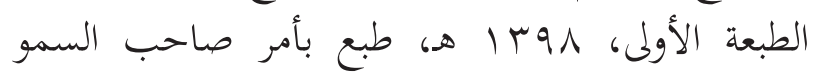

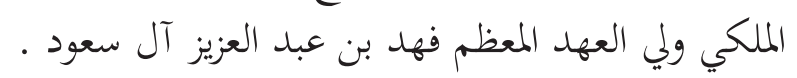
الجزري، ابن الأثير : الإمام محمد بن أبي السعادات المبارك

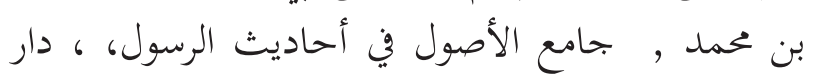

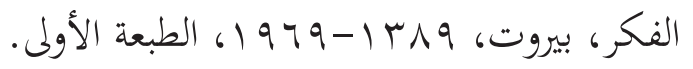

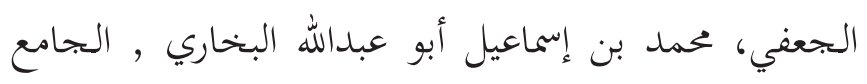

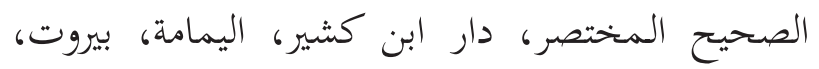

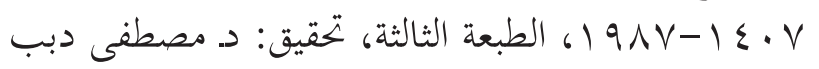

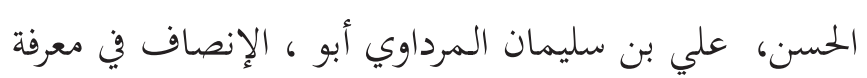

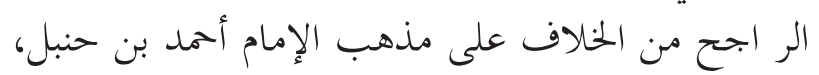
دار التراث العربي، بيروت، نحقيق : محمد حامد الخدام الفقي.

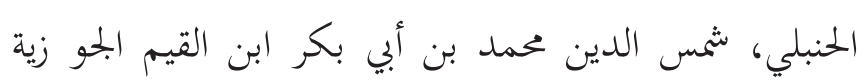

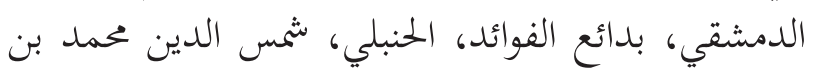

بالاستقراء التام أن البخاري يلتزم إيراد كل ما ورد فيما ترجم

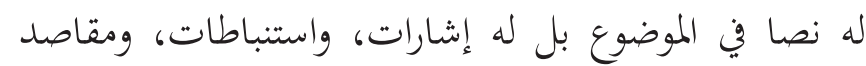

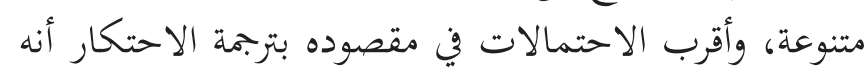

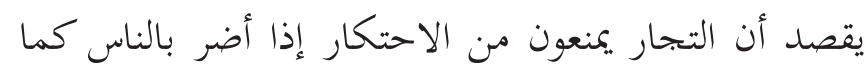

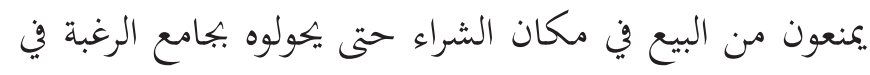

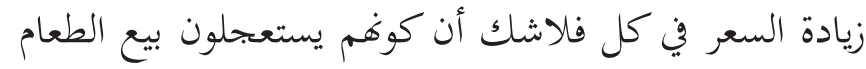

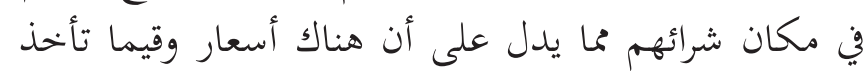

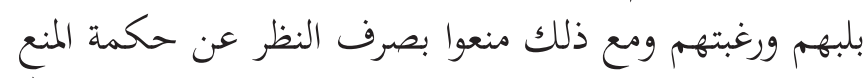

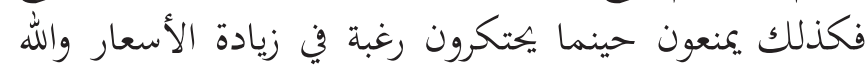
أعلم... فينك ويحتمل أن البخاري يرى أن الاحتكار خاص بالطعام ولأجل ذلك قرنه ببيع الطعام. وقد يفهم من الحديث الثاني أن العلة في منع بيع الطعام قبل

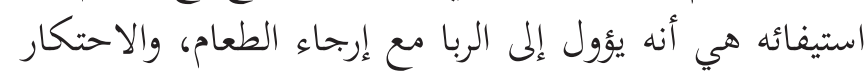

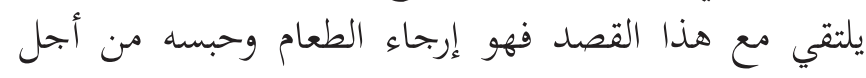
الدراهم وزيادةّا فيفهم منه المنع في ذلك. ومما يلاحظ أن الإمام مالك رحمه الله أورد ترجمة الاحتكار

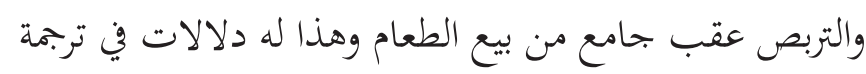
البخاري في الجمع بينهما، والله أعلم.

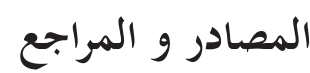

الأردي، سليمان بن الأشعث أبو داود السجستاني , سنن أبي داود، دار الفكر، تحقيق: محمد محيي الدين عبد الحميد.

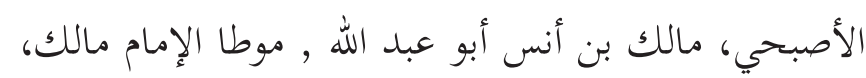

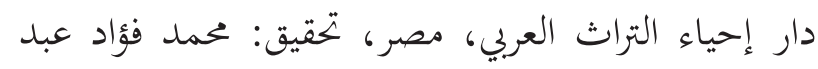
الباقي.

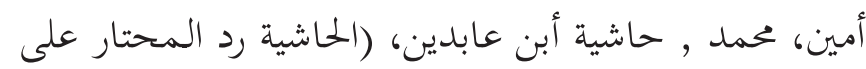

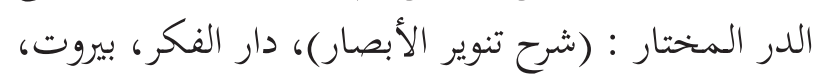

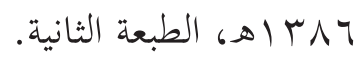

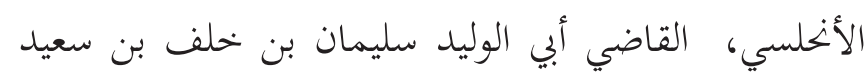

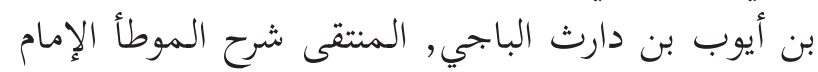

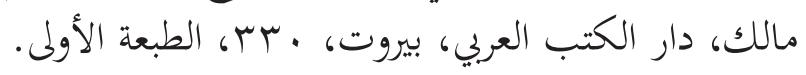
البخاري، أبي الطيب صديق بن حسن بن علي الحسيني

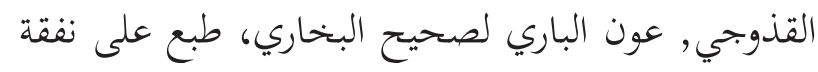

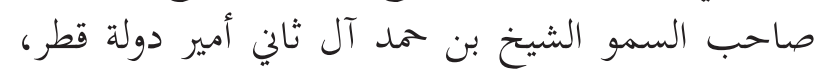




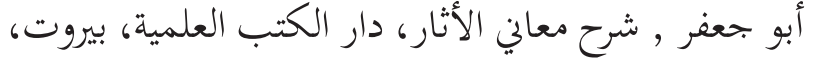

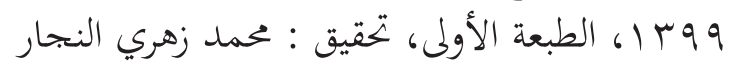
الطيب, محمد شمس الحق العظيم آبادي أبو، عون المعبود

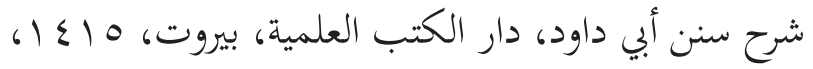
الطبعة الثانية.

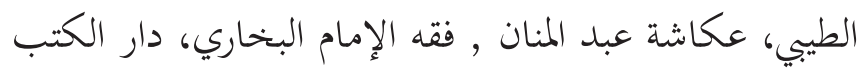

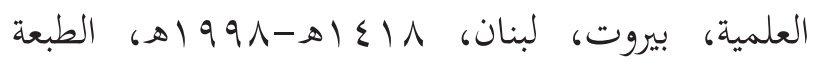
الأولى,

العسقلاني، أحمد بن حجر أبو الفضل، فتح الباري شرح

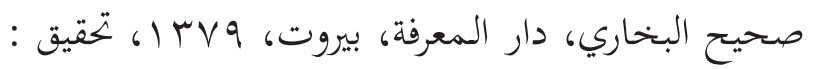
محمد فؤاد عبد الباقي، محب الدياري، دار الدعفة بين الخطيب. العيني، بدر الدين العيني أبي محمود بن أحمد , عمدة القاري شرح صحيح البخاري، دار الفكر. القزويني , محمد بن يزيد أبو عبدالله , سنن ابن ماجه، دار

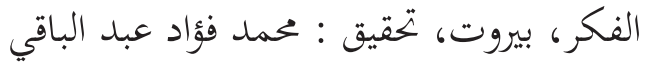

القسطلاني, أبي العباس أحمد ، إرشاد الساري شرح صحيح

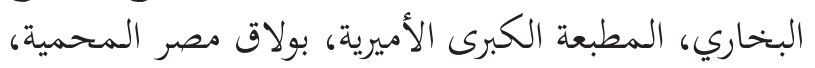

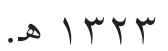

الكاساني، علاء الدين الكاساني، بدائع الصنائع في ترتيب

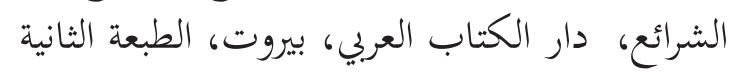

الكرماني، بشرح، صحيح البخاري, المطبعة المصرية، كاله ror

عبد اللطيف.

الكندهلويو, محمد زكريا بن, الأبواب والتراجم الصحيح البخاري، المكتبة الخيلية، الهند.

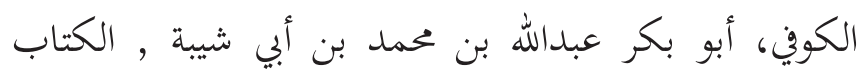

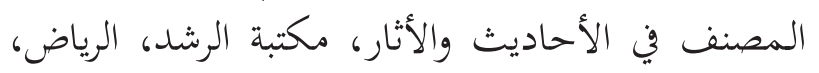

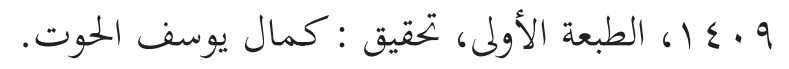

محمد، عبد الله بن أحمد بن قدامة المقدسي أبو, المغني في

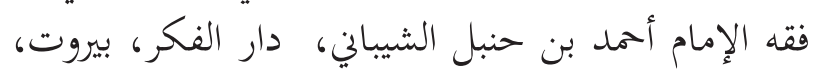

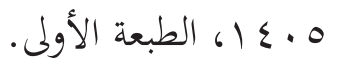

محمد، علي بن أحمد بن سعيد بن حزم الظاهري أبو ,

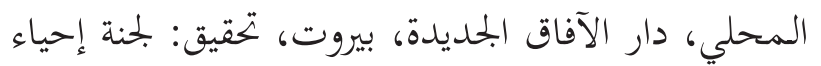

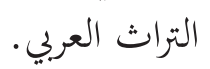

أبي بكر ابن القيم الجو زية الدمشقي الحنبلي، دار الفكر.

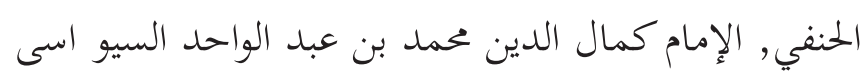

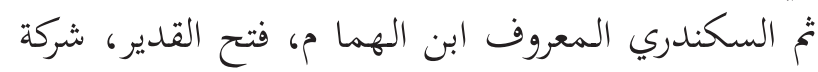

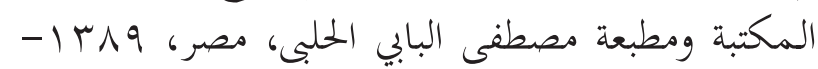
(9V.

الخالق ,الدكتور عبد الغاني عبد ، الإمام البخاري وصحيحه،

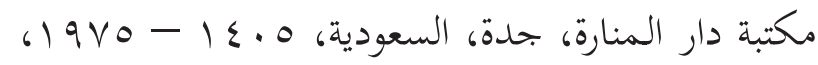

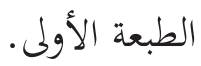

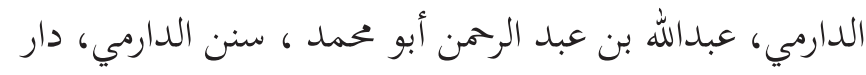

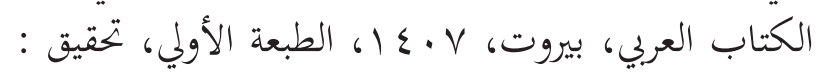

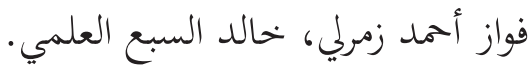

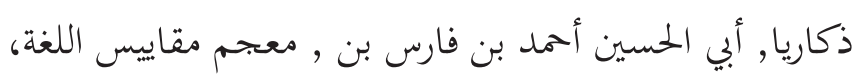

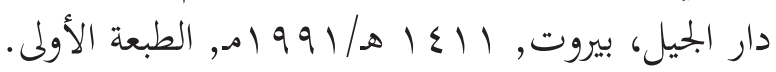

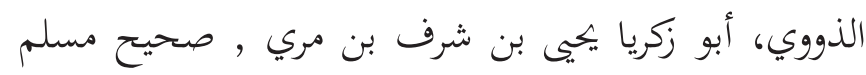

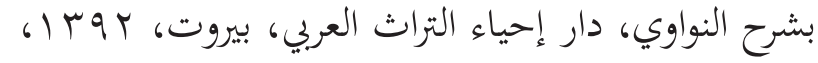
الطبعة الثانية

الذيسابوري، محمد بن إسحاق بن خزيمة أبوبكر السلمي, المبكا

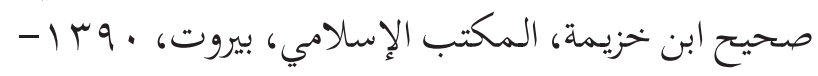

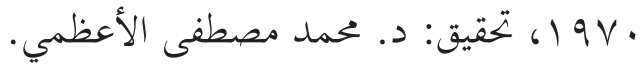
الرافعي، فتح العزيز، بهامش المحموع، الطبعة دار الفكر .

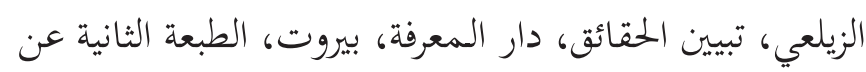

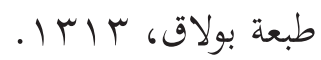

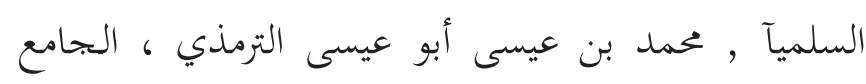

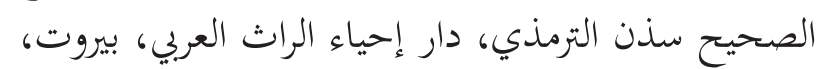
تحقيق: أحمد شاكروآخرون.

الشوكاني، محمد بن علي بن محمد, نيل الأوطار من أحاديث

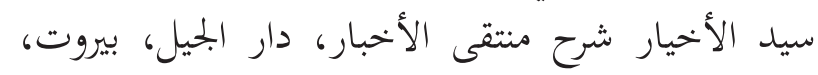
$.19 V \pi$

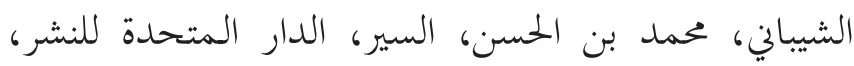

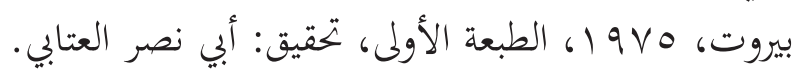

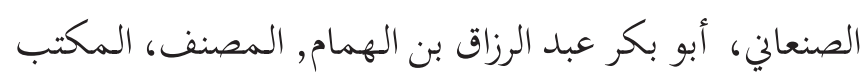

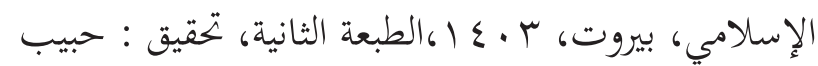
الرحمن الأعظمي. - (الإني، بروت الطحاوي، أحمد بن محمدبن سلامة بن عبد الملك بن سلمة 
268 Ahkam: Vol. XV, No. 2, Juli 2015

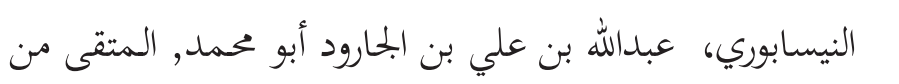

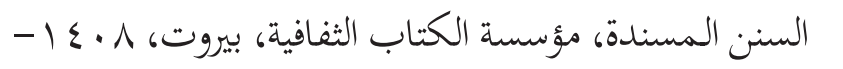
19 19 1، الطبعة الأولى، تحقيق: عبدالله عمر البارودي.

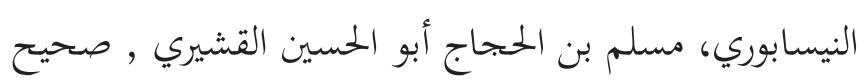

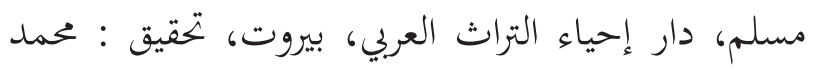

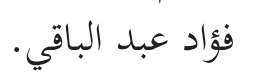

المصري, لإمام العلامة أبي الفضل جمال الدين محمد بن مكرم

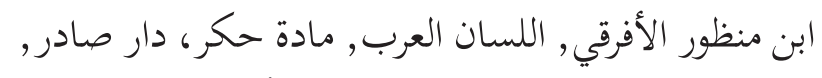

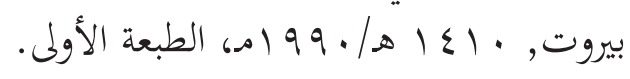

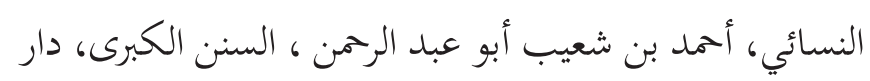

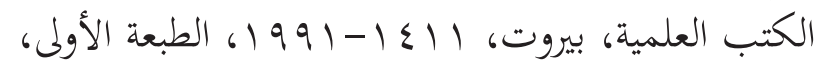

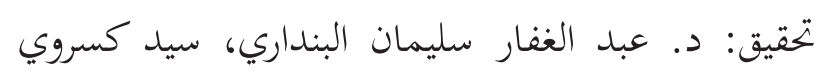

